\title{
Mapping premature ovarian insufficiency and potential environmental factors: A tool for triggering in-depth research of the problem in Slovenia
}

\author{
Živa Miriam Geršak, ${ }^{1}$ Ksenija Geršak,,${ }^{1,2}$ Tanja Rejc, ${ }^{3}$ Lucija Perharič, ${ }^{4}$ \\ Lijana Zaletel-Kragelj, ${ }^{3,4}$ Andreja Kukec ${ }^{3,4}$
}

${ }^{1}$ University of Ljubljana, Faculty of Medicine; ${ }^{2}$ Division of Obstetrics and Gynaecology, University Medical Centre Ljubljana; ${ }^{3}$ University of Ljubljana, Faculty of Medicine, Centre of Public Health;

${ }^{4}$ National Institute of Public Health, Slovenia

\begin{abstract}
Aiming at triggering in-depth research of the problem of Premature Ovarian Insufficiency (POI) in Slovenia, we assessed the regional differences in POI incidence emphasising the relationship with social and physical environmental factors at the population level using a mapping approach. The differences in POI incidence between regions were tested by goodness-of-fit chi-square test, while Pearson correlation coefficient was used to assess the ecological relationship between POI incidence and selected environmental indicators. Significant indicators were mapped. The results showed highly significant interregional differences in POI incidence $(p<0.001)$. Statistically significant ecological relationships were observed between POI incidence and prevalence of active smoking ( $p=0.001)$, passive smoking $(p=0.017)$ and consumption of vitamins $(p=0.008)$. The results could be used in diminishing interregional differences in POI. It was concluded that mapping is an effective tool in public health research, especially in triggering new activities.
\end{abstract}

Correspondence: Andreja Kukec, University of Ljubljana, Faculty of Medicine, Centre of Public Health

Zaloška 4, 1000 Ljubljana, Slovenia

Tel.: +38615437566

Fax.: +386 15437541

E-mail: andreja.kukec@mf.uni-lj.si

Key words: Premature ovarian insufficiency; risk factors; epidemiology; population-level research; mapping; Slovenia.

Acknowledgements: The authors want to thank the staff of the NIPHS for providing dataset on observed health outcome, and Vid Vičič for help in systematic review of the literature.

Conflicts of interest: The authors declare no conflict of interest.

Received for publication: 14 July 2019.

Accepted for publication: 11 February 2020.

(C) Copyright: the Author(s), 2020

Licensee PAGEPress, Italy

Geospatial Health 2020; 15:800

doi:10.4081/gh.2020.800

This article is distributed under the terms of the Creative Commons Attribution Noncommercial License (CC BY-NC 4.0) which permits any noncommercial use, distribution, and reproduction in any medium, provided the original author(s) and source are credited.

\section{Introduction}

Infertility is a problem of global proportions, affecting on average almost a tenth of couples (Boivin et al., 2007). One of the causes is Premature Ovarian Insufficiency (POI) (Podfigurna-Stopa et al., 2016), a syndrome defined as loss of ovarian activity in a woman before the age of 40 (ESHRE, 2015). In addition to infertility, several serious health problems, including psychological distress, osteoporosis and ischemic heart disease seems to be aggravated by POI (Podfigurna-Stopa et al., 2016; Jankowska et al., 2017). Although prevalence or incidence data of POI are scarce, approximately one in 10,000 women by the age of 20 years, and one in 100 by the age of 40 years are affected (ESHRE, 2015).

The causes of POI are diverse and can be divided into genetic, metabolic, autoimmune and iatrogenic (De Vos et al., 2001; Nelson, 2009). More recent reports indicate an important relationship between POI and various environmental factors. Among those with a potential origin in the physical environment, the Endocrine Disruptors (EDs) are the most obvious (Craig et al., 2011; Gore et al., 2011; Costa et al., 2014). Grindler et al. (2015) have demonstrated an association with Polychlorinated Biphenyls (PCBs), dioxins, furans, phthalates and certain pesticides ( $\beta$-hexachlorocyclohexane, mirex, p,p'-DDE) with a lower age at menopause. In addition, associations have been confirmed for the exposure to perfluorochemicals (Knox et al., 2011; Wang et al., 2015), phthalates (Hannon et al., 2015; Vabre et al., 2017), Polycyclic Aromatic Hydrocarbons (PAHs) (Iorio et al., 2014), and bisphenol A (Iorio et al., 2014; Caserta et al., 2014; Patel et al., 2015; Vabre et al., 2017). Furthermore, social environmental factors, especially behavioural ones, have been linked to POI. The most obvious association has been made for tobacco smoking with past research showing that active smokers reach menopause earlier than women who never smoked, and a hazard ratio of POI significantly higher compared to never-smokers (Prospero et al., 2003; Yang et al., 2015; Hyland et al., 2016; Whitcomb et al., 2018). Other possible associations between POI and behavioural factors are dietary habits and, consequently, the nutritional status. Namely, higher Body Mass Index (BMI) has been found to be associated with higher age at menopause (Akahoshi et al., 2002; Morris et al., 2012), while other recent studies indicate a relationship between POI and several trace substances, such as zinc and copper (Kebapcilar et al., 2013; Verma et al., 2018), selenium (Verma et al., 2018), calcium (Purdue-Smithe et al., 2017) and vitamin D (Kebapcilar et al., 2013, Purdue-Smithe et al., 2017).

In Slovenia, the problem was put on the agenda more than a decade ago (Meden-Vrtovec, 2007). According to the data of the National Institute of Public Health of Slovenia (NIPHS) for the last 
decade, the annual incidence of POI is about 2 to 4 per 10,000 women aged less than 40 years (NIJZ, ZUBSTAT, 2018). In addition, the average age of mothers when giving birth to the first child is constantly increasing in the country (1987: 23.3 years, 2017: 29.4 years) (Statistical Office of the Republic of Slovenia, 2018a), while the birth rate per 1000 population is decreasing (2010: 10.9, 2017: 9.8) (Statistical Office of the Republic of Slovenia, 2018a). Differences in POI incidence across the geographical regions have been noticed but so far have not been statistically confirmed. However, it is been suggested that they could be due to social and physical environmental factors (Geršak, 2016).

Aiming at laying the foundations for planning an evidence-based, in-depth research plan of the problem, the objective of the present study was to assess the geographical distribution of the POI burden in Slovenia, with special reference to possible relationships with social and physical environmental factors at the population level. In this process, we planned to use geographical mapping, which is a tool that has already been shown to be effective in presenting health problems to decision makers in Slovenia (Kukec et al., 2014a; Kukec et al., 2014b).

\section{Materials and Methods}

\section{Study design, study population, time frame and spatial units of observation}

The study was designed as an ecological multiple-group comparison (Morgenstern, 1982). The study population included women aged 15 to 39 years, residing permanently in Slovenia, who had visited Community Health Centres or other primary level healthcare units due to oligo/amenorrhea in the period January 1, 2003 to December 31, 2013. As spatial units of observation, the following 12 regions of Slovenia, valid for the observed time interval, were selected: Mura Region (MUSR), Drava Region (DRSR), Carinthia Region (CASR), Savinja Region (SASR), Central Sava Region (CSSR), Lower Sava Region (LSSR), Southeast Region (SESR), Central Slovenia Region (CESSR), Upper Carniola Region (UCSR), Inner Carniola-Karst Region (ICKSR), Gorizia Region (GOSR) and Coastal-Karst Region (CKSR).

\section{The observed outcome indicator}

The observed outcome was the presence of POI in a single woman, while for the observed outcome indicator, the incidence rate of POI, expressed according to the International Agency for Research on Cancer (IARC) and registered according to Boyle et al. (1991) was used as follows:

$$
I R=\frac{\Sigma \text { Number of new cases of } P O I}{\Sigma P e r s o n-y e a r s \text { at risk }} \times 100,000
$$

where 'IR' is the incidence rate; ' $\Sigma$ Number of new cases of POI' the total number of new cases of POI for each year $(2003,2004, \ldots .2013)$ observed; and ' $\Sigma$ Person-years at risk' the total population on July, 1 at regions in Slovenia observed for women aged 15-39 years these years. For the calculations of POI incidence, the NIPHS Out-patient Primary Level Healthcare Database (ZUBSTAT) (NIJZ, SUBSTAT, 2018) and the population data from the Statistical Office of the Republic of Slovenia (2018b) were used. The inclusion criteria were: cessation of menstrual cycle before 40 years of age and clin- ical presentation of ovarian insufficiency. Only women diagnosed according to ICD-10 as primary ovarian failure (ICD E28.3) or menopausal and female climacteric states (N95.1) were included in the study. Affiliation to the region was determined according to the location of the healthcare unit where the disease was diagnosed.

\section{Indicators on selected social and physical environment risk factors for POI}

In Slovenia, both individual-level and population-level data are available for the assessment of people's exposure to different environmental risks. Among the individual-level databases of potential use for our study, the most relevant information was provided by the Countrywide Integrated Non-communicable Disease Intervention (CINDI) Health Monitor Slovenia database (CHMS), which contains data of interval cross-sectional studies on behavioural risk factors for non-communicable diseases in adults since 2001 (Zaletel-Kragelj et al., 2004). Data for 2001, collected as part of research project risk factors for non-communicable disease in adults in Slovenia (leading partner: University of Ljubljana, Faculty of Medicine), were used. For the purpose of our study, the following four social environmental indicators from CHMS were included in the analysis: prevalence of active smoking, prevalence of passive smoking, prevalence of consumption of vitamins and prevalence of obesity (all of them expressed as percent of the total population). Prevalence of frequent consumption (daily or several times a day) of soft drinks from plastic bottles (expressed likewise), was included as a proxy indicator for exposure to EDs (Tzatzarakis et al., 2017).

Among the population-level databases, that were potentially useful in our study, the most relevant information was provided from results of the project 'Research of the pollution of the soil in Slovenia' (ROTS). Data from 2004 to 2008 were used (Zupan, 2005; Zupan, 2009). Median values of pollutant's concentrations were determined for measurements from all sites within each region. For the purposes of our study, three physical environment indicators from ROTS were included in the analysis: median zinc concentration, median copper concentration, and median concentration of some polycyclic aromatic hydrocarbons (atracen, benzo(a)piren, benzo(a)antracen, benzo(GHI) perilen, benzo(k)fluoranten, fenantren, fluoranten, indeno(123-cd)piren, krizen, naftalen, acenaften, acenaftilen, benzo(b)fluoranten, dibenzen(a,h)antracen, flouren, piren), all in $\mathrm{mg} / \mathrm{kg}$ of soil.

\section{Methods of analysis}

Differences in POI incidence between regions were tested by using goodness-of-fit chi-square test. The Pearson correlation coefficient was used to assess the ecological relationship between POI incidence and selected indicators of social and physical environmental factors. Mapping of POI incidence and environmental indicators, expressed as at least statistical borderline relationship with POI incidence, was done by using Geographical Information System (GIS) by ArcGIS v. 10.5.1 (ESRI, Redlands, CA, USA). In the process, the values of each indicator were graded using a 12-level scale (different shades of grey). Additionally, numerical values of indicators were displayed on the maps. All statistical analyses were made with SPSS 21.0 software package (SPSS Inc., Chicago, IL, USA). A $p$-value of $\leq 0.05$ was considered as statistically significant. 


\section{Results}

\section{Description of units of observation}

Table 1 shows the main demographic and socio-economic data for the Slovenian regions for the year in 2016 (Statistical Office of the Republic of Slovenia, 2018c), which are needed as background knowledge for the study of the geographical distribution of the POI burden in the country.

\section{Premature ovarian insufficiency incidence}

In an 11-year timeframe, there were 1,034 newly discovered cases of POI in Slovenia. For the entire observed period, the mean POI incidence rate in women aged 15-39 years was 28.0 per 100,000. The rate varied considerably between the regions (Figure 1) with differences statistically highly significant $(p<0.001)$. Among the individual regions, the highest mean POI incidence rate was in the CSSR region, i.e. 6.9-times higher than in the UCSR region, which was the lowest (Figure 1).

\section{Premature ovarian insufficiency in relation to selected social environmental indicators}

The correlation analysis showed a statistically significant relationship at the population level between POI incidence and prevalence of active smoking $(\mathrm{r}=0.812, p=0.001)$, prevalence of passive smoking $(\mathrm{r}=0.670, p=0.017)$, and prevalence of consumption of vitamins $(\mathrm{r}=-$ $0.723, p=0.008)$. The geographical distribution of these indicators by region is presented in Figure 2. The relationship between POI incidence and prevalence of obesity was not statistically significant $(r=0.057$, $p=0.861$ ).

\section{Premature ovarian insufficiency and selected physical environment indicators}

The correlation analysis showed no statistically significant relationship at the population level between POI incidence and selected physical environment indicators. However, the relationship between
POI incidence and prevalence of frequent consumption of soft drinks $(\mathrm{r}=0.521, p=0.082)$, and median concentration of sum of polycyclic aromatic hydrocarbons (PAHs) was on the border of statistical significance $(\mathrm{r}=0.426, p=0.167)$. The geographical distribution of these two indicators by region is presented in Figure 3. The relationship between POI incidence and the median zinc concentration $(\mathrm{r}=-0.100, p=0.758)$, as well as the median copper concentration $(\mathrm{r}=-0.116, p=0.720)$, were not statistically significant.

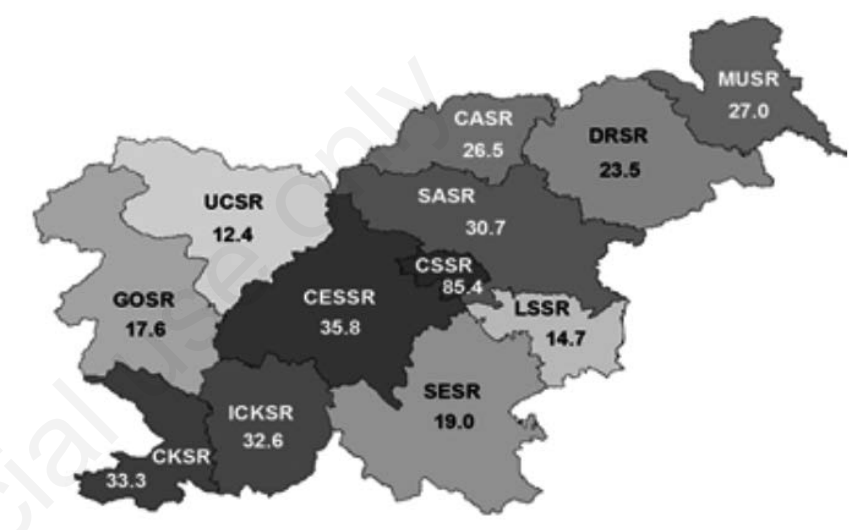

Figure 1. Incidence rate of premature ovarian insufficiency per 100,000 women aged from 15 to 39 years in the different regions of the Republic of Slovenia 2003-2013. MUSR=Mura Region, DRSR=Drava Region, CASR=Carinthia Region, SASR=Savinja Region, CSSR=Central Sava Region, LSSR=Lower Sava Region, SESR=Southeast Region, CESSR=Central Slovenia Region, UCSR=Upper Carniola Region, ICKSR=Inner Carniola-Karst Region, GOSR=Gorizia Region, CKSR=Coastal-Karst Region.

Table 1. Main demographic and socio-economic characteristics of Slovenian regions in 2016.

\begin{tabular}{lcccccc} 
Region & Population & $\begin{array}{c}\text { Total } \\
\text { increase* }\end{array}$ & $\begin{array}{c}\text { Mean age } \\
\text { of the population } \\
\text { (years) }\end{array}$ & $\begin{array}{c}\text { Registered } \\
\text { unemployment } \\
\text { rate (\%) }\end{array}$ & $\begin{array}{c}\text { Average } \\
\text { income** } \\
\text { (EUR) }\end{array}$ & $\begin{array}{c}\text { Turnover of } \\
\text { enterprises*** } \\
\text { (EUR) }\end{array}$ \\
MUSR & 115,818 & -5.0 & 45.0 & 17.0 & 940 & $2,836,447$ \\
DRSR & 321,493 & -1.6 & 43.7 & 12.5 & 955 & $10,451,382$ \\
\hline CASR & 71,010 & -3.9 & 43.5 & 10.6 & 981 & $2,140,636$ \\
SASR & 254,824 & 1.7 & 42.7 & 12.4 & 954 & $9,600,906$ \\
\hline CSSR & 57,466 & -2.1 & 43.8 & 13.9 & 933 & $1,007,416$ \\
LSSR & 75,694 & -2.2 & 43.4 & 12.8 & 976 & $3,587,313$ \\
\hline SESR & 142,672 & 1.0 & 42.1 & 11.7 & 1,036 & $5,980,393$ \\
CESSR & 537,893 & 4.9 & 41.5 & 7.1 & 1,118 & $45,134,702$ \\
\hline UCSR & 203,654 & -0.1 & 42.5 & 10.1 & 1,025 & $7,074,340$ \\
ICKSR & 52,593 & 1.1 & 43.3 & 8.7 & 925 & $1,467,986$ \\
\hline GOSR & 117,931 & -2.7 & 44.2 & 10.1 & 1,007 & $4,122,753$ \\
CKSR & 113,193 & 4.0 & 44.1 & 1,015 & $5,169,354$ \\
\hline
\end{tabular}

MUSR=Mura Region, DRSR=Drava Region, CASR=Carinthia Region, SASR=Savinja Region, CSSR=Central Sava Region, LSSR=Lower Sava Region, SESR=Southeast Region, CESSR=Central Slovenia Region, UCSR=Upper Carniola Region, ICKSR=Inner Carniola-Karts Region, GOSR=Gorizia Region, CKSR=Coastal-Karst Region; *per 1,000 population; **monthly net earnings per person in paid employment; *** $\times 1,000$. 


\section{Discussion}

Our study showed clear important differences in POI incidence between Slovenian regions. An association between POI incidence and majority of considered environmental factors was also found at the population level. Specifically, geographical analysis revealed the CSSR region to have the highest POI incidence and to be among the most unfavourable with respect to some environmental indicators, for example passive smoking, consumption of soft drinks and concentration of polycyclic aromatic hydrocarbons, which were expressed as significant or borderline significant relationship with POI incidence. These outcomes were expected, as previous studies have found this area problematic, both from the perspective of health (Eržen et al., 2006; Kukec et al., 2014c) and that of environmental pollution (Bolte et al., 2009). Moreover, our findings support to some extent the results of the study of Eržen et al. (2006), which indicated the possibility of an association between reproductive health outcomes and environmental pollution.

Regarding the relationship between POI and environmental factors, comparisons with other studies can only be partial, as our study was a population-level study, while others were done at the individual level. Nevertheless, the results for the majority of indicators are in the same direction. Among the social environmental factors, we found a strong positive relationship at the ecological level between POI and active as well as passive smoking. This is in line with previous studies (Prospero et al., 2003; Yang et al., 2015; Hyland et al., 2016; Whitcomb et al., 2018). Along with Kebapcilar et al. (2013) and Purdue-Smithe et al. (2017), we found strong negative association between POI and consumption of vitamins. On the other hand, we found no ecological relationship with obesity (expressed as BMI), which is in contrast to the results by Akahoshi et al. (2002) and Morris et al. (2012), who concluded that the greater the BMI, the later the age of menopause. Furthermore, no association between the POI incidence and consumption of soft drinks, and POI incidence and concentration of PAHs was found.

At the ecological level, we see that our results coincide roughly with the results of research on relationship of POI and EDs like phthalates (Caserta et al., 2014; Vabre et al., 2017), bisphenol A (Iorio et al., 2014 ; Caserta et al., 2014 ; Patel et al., 2015; Vabre et al., 2017), and PAHs (Iorio et al., 2014). On the other hand, the association between the trace substances zinc and copper in soil and POI incidence found in this study was far from statistical significance, what is contrary to the results of other investigations at the individual level (Vabre et al., 2017; Verma et al., 2018).

This study has some limitations. First, the population-based scale might be a problem. However, from the public health perspective studies like these are crucial, as they provide evidence at a level which is useful for the development of health policies, e.g., considering environmental health. Already more than two decades ago, the World Health Organisation (WHO) stated the need for such studies as very important for politicians (Briggs et al., 1996). Second, all the data used in this study were only from the primary healthcare level, consequently, some data were not taken into account, as in Slovenia women can choose their personal gynaecologist also at secondary or tertiary level healthcare. However, this limitation could be considered as a minor, as the vast majority of women=choose their personal gynaecologist at primary healthcare level, hence, the vast majority of POI diagnoses are set at this level. Third, the regional affiliation of the study subjects was determined according to the location of the healthcare unit where the disease was diagnosed and not according to the permanent residence of the individual female patients. However, due to strict rules of regarding exact geolocation of data that recently have been introduced into Slovenian health databases, private addresses cannot be used. An attenuating circumstance is that women in Slovenia, in the vast majority, choose their gynaecologist in the vicinity of their place of residence. Fourth, only basic statistical methods were used in the analysis as sophisticated statistical methods demand larger datasets to operate accurately. If data from different databases could be accessed and prepared at the level of smaller spatial units, this would be possible. Furthermore, adjusting for confounding factors was not taken into consideration in our analysis, which again could not have been done

a)

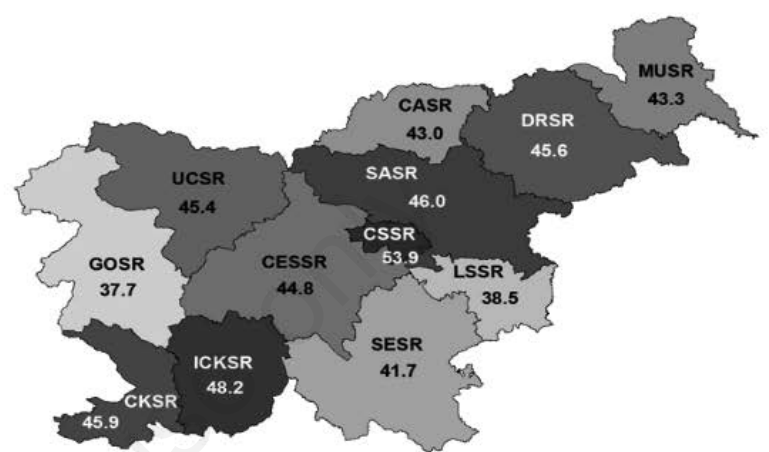

b)

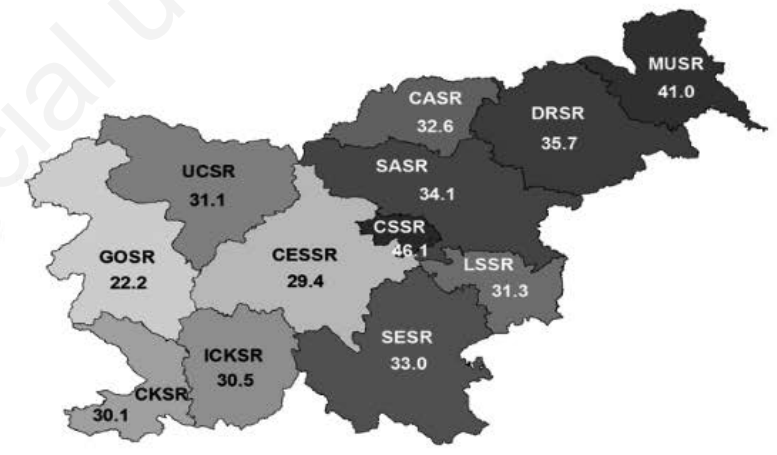

c)

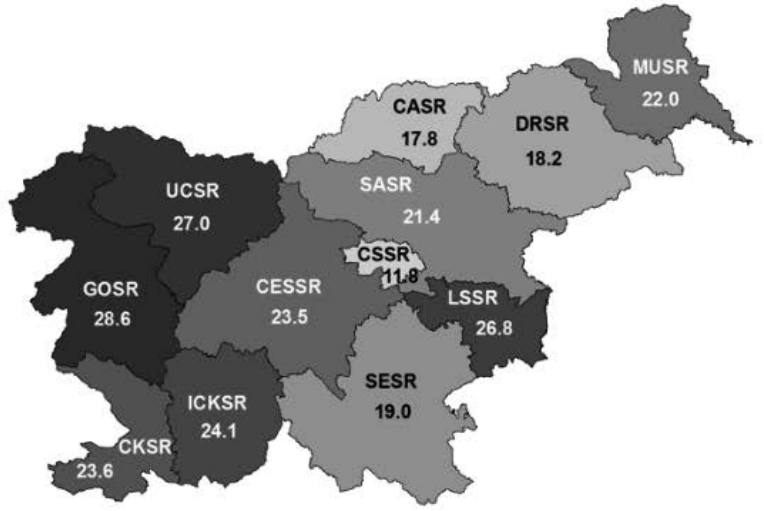

Figure 2. Geographical distribution of selected social environment indicators in women in reproductive age in the different regions of the Republic of Slovenia. a) prevalence of active smoking; b) prevalence of passive smoking; c) prevalence of consumption of vitamins expressed in percent. MUSR=Mura Region, DRSR=Drava Region, CASR=Carinthia Region, SASR=Savinja Region, CSSR=Central Sava Region, LSSR=Lower Sava Region, SESR=Southeast Region, CESSR=Central Slovenia Region, UCSR=Upper Carniola Region, ICKSR=Inner Carniola-Karst Region, GOSR=Gorizia Region, CKSR=Coastal-Karst Region. 
because of the small number of observed units. Indeed, this study was launched to trigger/promote collection of larger environmental and health datasets that would allow adjusting confounding factors. So far, this is only possible in the case of CHMS indicators. Finally, despite the collection of other important information, such as data on drinking water quality and human biomonitoring, they could not be brought to the level needed for each observed spatial unit. Therefore, the analysis of physical environmental data included only data of soil contamination. Despite these limitations, this study must be deemed useful. Apart from emphasizing and sustaining research on POI, the strength of this study is that mapping has again been proved an effective tool in public health and we provide evidence of the usefulness of GIS in the public health field. GIS facilitates priority setting and analysis essential for spatial research and presentations to decision-makers. It is also useful for policy development and designing sustainable health care systems which has also been pointed out other authors (Nykiforuk et al., 2011; Taylor et al., 2012). That POI is on the national agenda in Slovenia is an important health outcome from recently started project entitled "An attempt to interpret the results of biomonitoring in conjunction with data on environmental pollution" (Horvat et al., 2019). At present, in its current form it offers some guidelines for designing/transforming public health measures in the field of environment and health. The significance of such kind of research is to help triggering activities like policies and strategies, which are an integral part of good public health governance. WHO has been putting such activities in the forefront for quite some time now (Kickbusch et al., 2012; Kickbusch et al., 2014). Our study has led to the need to improve existing databases in the field of health and environment in Slovenia. Ecological studies should provide information further expanding the reach of these databases that could prove essential when linkage between different datasets is attempted. Finally, it is felt that this study can serve as a model for future research as this kind of studies in the area of POI were found in the accessible literature.

\section{Implication for public health}

The results of the present study have important implication for public health in Slovenia. First, the results are directly applicable in transforming existing public health measures in the CSSR region. One of the fields of action is certainly smoking. According to data from subsequent CHMS studies (Zaletel et al., 2016), smoking among CSSR's adult population has been falling for some time since 2001, but has been growing since 2012. We propose that information obtained in our study, together with appropriate health promotion activities in this socio-economic and demographically non-prosperous region, should target the female adolescent population. We believe that POI is one of

a)

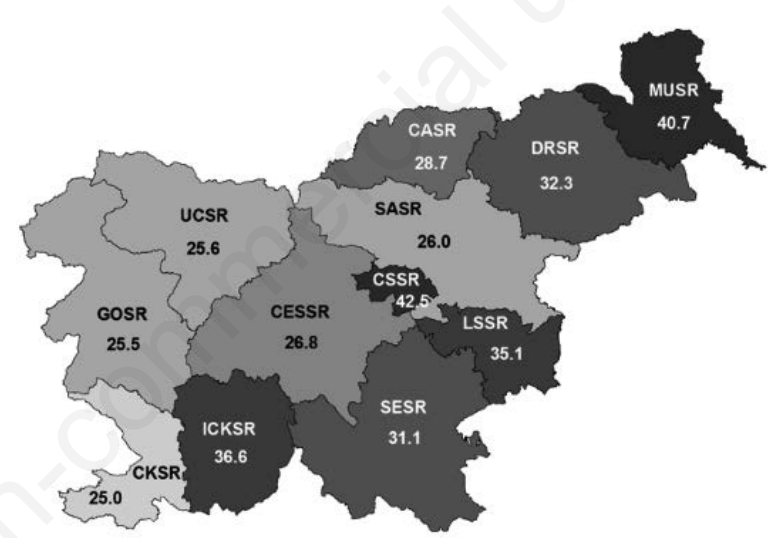

b)

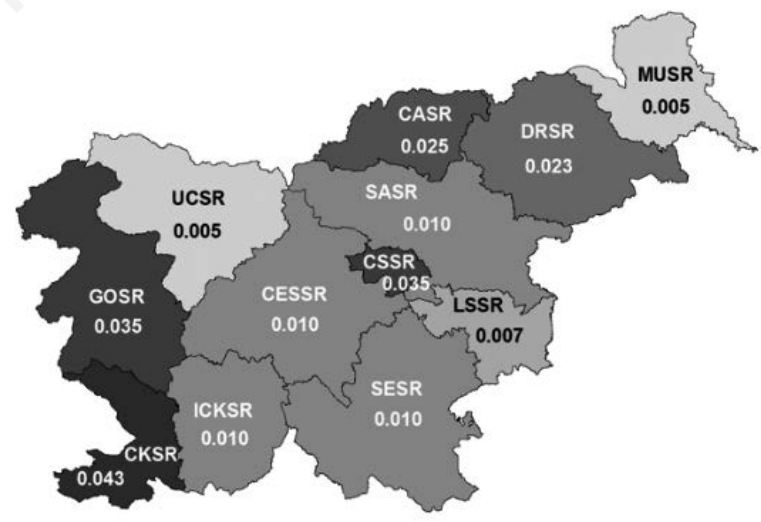

Figure 3. Geographical distribution of selected indicators of physical environment in women in reproductive age in the different regions of the Republic of Slovenia. a) prevalence of frequent consumption of soft drinks given as a proxy indicator for exposure to endocrine disrupters in plastic bottles; and b) prevalence of the median concentration of sum of polycyclic aromatic hydrocarbons (mg/kg soil).) expressed in percent. MUSR=Mura Region, DRSR=Drava Region, CASR=Carinthia Region, SASR=Savinja Region, CSSR=Central Sava Region, LSSR=Lower Sava Region, SESR=Southeast Region, CESSR=Central Slovenia Region, UCSR=Upper Carniola Region, ICKSR=Inner Carniola-Karst Region, GOSR=Gorizia Region, CKSR=Coastal-Karst Region. 
the many important consequences of smoking, which particularly affects young women more strongly than cancer, as this disease developed more slowly and is therefore known to be more frequent in older age groups.

This study represents an opportunity for improvement of existing databases in the field of health and environment making them available for meaningful integration and thus more cost-effective. The findings reported have an important implication for gynaecology in terms of involvement of potential environmental factors when POI is suspected. Therefore, an environmental history should be included as a part of diagnostic process.

In the near future, all relevant databases with reference to human biomonitoring (Perharič et al., 2012; Horvat et al., 2015a; Horvat et al., 2015b), already in progress including quality data on drinking water (Slovenian Environment Agency, 2018) should be operated in a way enabling comprehensive information for understanding of the relationship between various health outcomes and environmental factors. It is particularly important to determine the suitable spatial unit of observation, which could be determined administratively, or on another basis (Morgenstern, 1982). In our opinion, inclusion of geolocation data into the existing health databases could be particularly useful.

\section{Conclusions}

The study has shown clearly evidence of existing important differences in POI incidence between Slovenian regions that might be attributed to regional differences with respect to certain indicators of social and physical environment. Mapping has again proved to be an effective tool in public health, and our research presents an opportunity for improvement of existing databases in the field of health and environment. The study should be seen as an attempt to diminish the burden on POI incidence in Slovenia.

\section{References}

Akahoshi M, Soda M, Nakashima E, Tominaga T, Ichimaru S, Seto S, Yano K, 2002. The effects of body mass index on age at menopause. Int J Obes Relat Metab Disord 26:961-8.

Boivin J, Bunting L, Collins JA, Nygren KG, 2007. International estimates of infertility prevalence and treatment-seeking: potential need and demand for infertility medical care. Hum Reprod 22:1506-12.

Bolte T, Segula A, Fasing J, Rode B, Lesnjak M, Gartner D, Gjerek M, Lesnik M, Turk D, 2009. [Ocena onesnaženosti zraka $\mathrm{SO}_{2}$, $\mathrm{NO}_{2}, \mathrm{PM}_{10}$, svincem, $\mathrm{CO}$, benzenom, težkimi kovinami in policikličnimi aromatskimi ogljikovodiki v Sloveniji. Assessment of air pollution of $\mathrm{SO}_{2}, \mathrm{NO}_{2}, \mathrm{PM}_{10}$, lead, $\mathrm{CO}$, benzene, heavy metals and polycyclic aromatic hydrocarbons in Slovenia.] Ljubljana: EARS Publications. [Article in Slovenian].

Boyle P, Parkin DM, 1991. Statistical methods for registries. In: Jensen OM, Parkin DM, MacLennan R, Muir CS, Skeet RG. Cancer Registration: Principles and methods. Lyon, France: International Agency for Research on Cancer, pp. 126-58.

Briggs D, Corvalan C, Nurminen M, 1996. Linkage methods for environment and health analysis. General guidelines. Geneva: World Health Organization.

Caserta D, Di Segni N, Mallozzi M. Giovanale V, Mantovani A, Marci R, Moscarini M, 2014. Bisphenol A and the female reproductive tract: An overview of recent laboratory evidence and epidemiological studies. Reprod Biol Endocrinol 9:12:37.

Costa EM, Spritzer PM, Hohl A, Bachega TA, 2014. Effects of endocrine disruptors in the development of the female reproductive tract. Arq Bras Endocrinol Metabol 58:153-61.

Craig ZR, Wang W, Flaws JA, 2011. Endocrine-disrupting chemicals in ovarian function: Effects on steroidogenesis, metabolism and nuclear receptor signalling. Reproduction 142:633-46.

De Vos M, Devroey P, Fauser BCJM, 2001. Primary ovarian insufficiency. The Lancet 376:911-21.

Eržen I, Vertačnik G, Podkrajšek D, Juričič M, Uršič A, Zadnik V, 2006. [Proučevanje vpliva okolja na pojav določenih bolezni in povečano stopnjo umrljivosti prebivalcev na območju občine Zagorje ob Savi: Zaključno poročilo.] Study of the influence of the environment on the occurrence of certain diseases and the increased mortality rate of the population in the Zagorje ob Savi municipality: Final report. Celje, Zavod za zdravstveno varstvo Celje. [Article in Slovenian].

European Society of Human Reproduction and Embryology (ESHRE), 2015. Management of women with premature ovarian insufficiency. Guideline of the European Society of Human Reproduction and Embryology. Grimbergen, European Society of Human Reproduction and Embryology.

Geršak K, 2016. Is the incidence of female reproductive disorders in Slovenia related to environmental factors? Eur J Obstet Gynecol Reprod Biol 206:e43.

Gore AC, Walker DM, Zama AM, Armenti AE, Uzumcu M, 2011. Early life exposure to endocrine-disrupting chemicals causes lifelong molecular reprogramming of the hypothalamus and premature reproductive aging. Mol Endocrinol 25:2157-68.

Grindler NM, Allsworth JE, Macones GA, Kannan K, Roehl KA, Cooper AR, 2015. Persistent organic pollutants and early menopause in U.S. Women. PLoS ONE. 10:e0116057.

Hannon PR, Flaws JA, 2015. The effects of phthalates on the ovary. Front Endocrinol 6:8.

Horvat M, Mazej D, Snoj Tratnik J, Šlejkovec Z, Jagodič M, Fajon V, Pavlin M, Stanjko A, Krsnik M, Prezelj M, 2015a. [Monitoring kemikalij in njihovih ostankov v ljudeh, 20112014. Zaključno poročilo o rezultatih kemijskih analiz za kovine in polkovine.] Monitoring of chemicals and their residues in humans, 2011-2014. Final report on analytical results for metals and half-metals. Ljubljana, Jožef Štefan Institute (Report No. 11794). [Article in Slovenian].

Horvat M, Baskar M, Cenčič-Kodba Z, Fajon V, Jagodič M, Križanec B, Krsnik M, Levačič-Turk Z, Mazej D, Pavlin M, 2015b. [Monitoring kemikalij in njihovih ostankov v ljudeh, 2011-2014. Zaključno poročilo o rezultatih kemijskih analiz.] Monitoring of chemicals and their residues in humans 20112014: final report on the results of chemical analyse. Ljubljana, Jožef Štefan Institute (Report No. 11985). [Article in Slovenian].

Horvat M, Snoj Tratnik J, Mazej D, Kocman D, Falnoga I, Stajnko A, Kukec A, Zaletel-Kragelj L, Šömen Joksić A, Rejc T, Eržen I, Hrženjak Viher V, Trebše P, Bavcon Kralj M, Kontić B, Bizjak T, Kontić D, 2019. [Poskus interpretacije rezultatov biomonitoringa $\mathrm{v}$ povezavi s podatki o onesnaženosti okolja, $\mathrm{s}$ poudarkom na onesnaženosti zraka in oceni potencialnih vplivov teh onesnažil na zdravje prebivalcev. Zaključno poročilo.] An attempt to interpret the results of biomonitoring in conjunction with data on environmental pollution, with an 
emphasis on air pollution and an assessment of the potential effects of these pollutants on the health of the population: final report]. Ljubljana, Jožef Štefan Institute. (Report No. C271518-634801). [Article in Slovenian].

Hyland A, Piazza K, Hovey KM, Tindle HA, Manson JE, Messina C, Rivard C, Smith D, Wactawski-Wende J, 2016. Associations between lifetime tobacco exposure with infertility and age at natural menopause: The women's health initiative observational study. Tob Control 25:706-14.

Iorio R, Castellucci A, Ventriglia G, Teoli F, Cellini V, Macchiarelli G, Cecconi S, 2014. Ovarian toxicity: From environmental exposure to chemotherapy. Curr Pharm Des 20:5388-97.

Jankowska K, 2017. Premature ovarian failure. Menopause Rev 16:51-6.

Kebapcilar AG, Kulaksizoglu M, Kebapcilar L, Gonen MS, Unlü A, Topcu A, Demirci F, Taner CE, 2013. Is there a link between premature ovarian failure and serum concentrations of vitamin D, zinc, and copper? Menopause 20:94-9.

Kickbusch I, Gleicher D, 2012. Governance for health in the 21st century. Copenhagen, WHO - World Health Organisation Regional Office for Europe.

Kickbusch I, Gleicher D, 2014. Smart governance for health and well-being: the evidence. Copenhagen, WHO - World Health Organisation Regional Office for Europe.

Knox SS, Jackson T, Javins B, Frisbee SJ, Shankar A, Ducatman AM, 2011. Implications of early menopause in women exposed to perfluorocarbons. J Clin Endocrinol Metab 96:1747-53.

Kukec A, Zaletel-Kragelj L, Farkaš-Lainščak J, Eržen I, Herakovič A, Božnar M, Mlakar P, Grašič B, Zadnik V, 2014a. Health geography in case of Zasavje: linking of atmospheric air pollution and respiratory diseases data. Acta geogr Slov 54:345-62.

Kukec A, Božnar M, Mlakar P, Grašič B, Herakovič A, Zadnik V, Zaletel-Kragelj L, Farkaš-Lainščak J, Eržen I, 2014 b. Methodological approach in determination of small spatial units in a highly complex terrain in atmospheric pollution research: the case of Zasavje region in Slovenia. Geospat Health 8:527-35.

Kukec $^{\mathrm{C}}$ A, Erzen I, Farkas J, Zaletel Kragelj L, 2014. Impact of air pollution with PM10 on primary health care consultations for respiratory diseases in children in Zasavje, Slovenia: a time-trend study. Zdrav Varst 53:55-68.

Meden-Vrtovec H, 2007. Premature ovarian failure: etiology, diagnostic and therapeutic procedures. Zdrav Vestn 76:551-7.

Morgenstern H, 1982. Uses of ecologic analysis in epidemiologic research. Am J Public Health 72:1336-44.

Morris DH, Jones ME, Schoemaker MJ, McFadden E, Ashworth A, Swerdlow AJ, 2012. Body mass index, exercise, and other lifestyle factors in relation to age at natural menopause: Analyses from the breakthrough generations study. Am J Epidemiol 175:998-1005.

Nacionalni Inštitut za Javno Zdravje (NIJZ), Zunajbolnišnična zdravstvena dejavnost (ZUBSTAT) [National Institute of Public Health, Out-patient Healthcare at Primary Level Database], 2018. Available from: URL:http://www.nijz.si/podatki/zunajbolnisnicnazdravstvena-dejavnost-0. [Website in Slovenian].

Nelson LM, 2009. Primary ovarian insufficiency. N Engl J Med 360:606-14.

Nykiforuk CI, Flaman LM, 2011. Geographic information systems (GIS) for Health Promotion and Public Health: a review. Health Promot Pract 12:63-73.
Patel S, Zhou C, Rattan S, Flaws JA, 2015. Effects of endocrinedisrupting chemicals on the ovary. Biol Reprod 93:20.

Perharič L, Vračko P, 2012. Development of national human biomonitoring programme in Slovenia. Int J Hyg Environ Health 215:180-4.

Podfigurna-Stopa A, Czyzyk A, Grymowicz M, Smolarczyk R, Katulski K, Czajkowski K, Meczekalski B, 2016. Premature ovarian insufficiency: the context of long-term effects. J Endocrinol Invest 39:983-90.

Prospero F, Luzi S, Iacopini Z, 2003. Cigarette smoking damages women's reproductive life. Reprod Biomed Online 8:246-7.

Purdue-Smithe AC, Whitcomb BW, Szegda KL, Boutot ME, Manson JE, Hankinson SE, Rosner BA, Troy LM, Michels KB, Bertone-Johnson ER, 2017. Vitamin D and calcium intake and risk of early menopause. Am J Clin Nutr 105:1493-501.

Slovenian Environment Agency. Drinking water quality data. Ljubljana: Slovenian Environment Agency, 2018. Available from: http://www.arso.gov.si/vode/podatki/

Statistical Office of the Republic of Slovenia'2018a. Births and Deaths. Available from: http://www.stat.si/StatWeb/ Field/Index/17/95

Statistical Office of the Republic of Slovenia, 2018b. Population by 5-year age groups and sex, statistical regions, Slovenia, annually. Available from: http://pxweb.stat.si/ pxweb/Dialog/varval.asp?ma=05C2004 $\mathrm{S} \& \mathrm{ti}=\&$ path $=. /$ Database/Dem_soc/05_prebivalstvo/10_stevilo_preb/ 10_05C20_prebivalstvo_stat_regije/\&lang=2

Statistical Office of the Republic of Slovenia, 2018c. Slovene statistical regions and municipalities in numbers (2016). Available from: http://www.stat.si/obcine/en/2016

Taylor DM, Yeager VA, Ouimet C, Menachemi N, 2012. Using GIS for Administrative Decision-Making in a Local Public Health Setting. Public Health Rep 127:347-53.

Tzatzarakis MN, Karzi V, Vakonaki E, Goumenou M, Kavvalakis M, Stivaktakis P, Tsitsimpikou C, Tsakiris I, Rizos AK, Tsatsakis AM, 2017. Bisphenol A in soft drinks and canned foods and data evaluation. Food Addit Contam Part B Surveill 10:85-90.

Vabre P, Gatimel N, Moreau J, Gayrard V, Picard-Hagen N, Parinaud J, Leandri RD, 2017. Environ-mental pollutants, a possible etiology for premature ovarian insufficiency: a narrative review of animal and human data. Environ Health 16:37.

Verma P, Sharma KA, Shankar H, Sharma A, Rao DN, 2018. Role of trace elements, oxidative stress and immune system: A triad in premature ovarian failure. Biol Trace Elem Res 184:325-33.

Wang H, Chen H, Qin Y, Qin Y, Shi Z, Zhao X, Xu J, Ma B, Chen ZJ, 2015. Risks associated with premature ovarian failure in Han Chinese women. Reprod Biomed Online 30:401-7.

Whitcomb BW, Purdue-Smithe AC, Szegda KL, Boutot ME, Hankinson SE, Manson JE, Rosner B, Willett WC, Eliassen AH, Bertone-Johnson ER, 2018. Cigarette Smoking and Risk of Early Natural Menopause. Am J Epidemiol 187:696-704.

Yang HJ, Suh PS, Kim SJ, Lee SY, 2015. Effects of Smoking on Menopausal Age: Results from the Korea National Health and Nutrition Examination Survey, 2007 to 2012. J Prev Med Public Health 48:216-24.

Zaletel-Kragelj L, Fras Z, Maučec Zakotnik J, 2004. [Tvegana vedenja, povezana $\mathrm{z}$ zdravjem in nekatera zdravstvena stanja pri odraslih prebivalcih Slovenije: rezultati raziskave Dejavniki tveganja za nenalezljive bolezni pri odraslih prebivalcih Slovenije (z zdravjem povezan vedenjski slog).] Risks related to health and certain health conditions in adult popula- 
tion of Slovenia: results of the research Risk Factors for NonCommunicable Diseases in Adult Residents of Slovenia (health-related behavioral style). Ljubljana, CINDI Slovenija. [Article in Slovenian].

Zaletel M, Vardič D, Hladnik M, 2016. [Zdravstveni statistični letopis.] Health Statistical Yearbook. Ljubljana, Nacionalni inštitut za javno zdravje. [Article in Slovenian].

Zupan M, 2005. [Raziskave onesnaženosti tal Slovenije v letu 2004: Poročilo.] Research of the pollution of the soil in
Slovenia in the year 2004: report. Ljubljana, Biotehniška fakulteta, Oddelek za agronomijo, Center za pedologijo in varstvo okolja. [Article in Slovenian].

Zupan M, 2009. [Raziskave onesnaženosti tal Slovenije v letu 2008: Poročilo.] Research of the pollution of the soil in Slovenia in the year 2008: report. Ljubljana, Biotehniška fakulteta, Oddelek za agronomijo, Center za pedologijo in varstvo okolja. [Article in Slovenian]. 